Check for updates

Cite this: RSC Adv., 2019, 9, 6021

\title{
A novel diarylethene-based fluorescent "turn-on" sensor for the selective detection of $\mathrm{Mg}^{2+\dagger}$
}

\author{
Zhen Wang, Shiqiang Cui, (D) * Shouyu Qiu and Shouzhi Pu* \\ A new photochromic diarylethene derivative with a 4-methylphenol unit has been designed and \\ synthesized. It displayed distinct photochromism and fluorescent "turn on" features to $\mathrm{Mg}^{2+}$ in \\ acetonitrile solution. With the addition of $\mathrm{Mg}^{2+}$, there was an obvious increase of fluorescent emission \\ intensity at $552 \mathrm{~nm}$, accompanied by a clear change of fluorescent color from dark purple to green. \\ Meantime, the $1: 1$ stoichiometry between the derivative and $\mathrm{Mg}^{2+}$ was verified by Job's plot and HRMS. \\ Furthermore, the sensor was successfully applied in the detection of $\mathrm{Mg}^{2+}$ in practical samples. \\ Moreover, based on the multiple-responsive fluorescence switching behaviors, it also could be used to \\ construct a molecular logic circuit with UV/vis lights and $\mathrm{Mg}^{2+} /$ EDTA as input signals and the emission at \\ $552 \mathrm{~nm}$ as the output signal.
}

Received 21st December 2018 Accepted 13th February 2019

DOI: 10.1039/c8ra10470k

rsc.li/rsc-advances simple operation. ${ }^{30-32}$ Up to now, various fluorescence sensors for $\mathrm{Mg}^{2+}$ have been developed. These sensors have different receptor groups based on moieties including diaza-18-crown- $6,{ }^{33}$ benzo-15crown- $5,{ }^{34}$ calix[4]arene, ${ }^{35}$ benzo-chromene, ${ }^{36}$ imidazo-1,10-phenanthroline,${ }^{37}$ and other functional units. ${ }^{38-42}$ However, most of the reported $\mathrm{Mg}^{2+}$ sensors have poor selectivity to $\mathrm{Mg}^{2+}$ and $\mathrm{Ca}^{2+}$, due to their similar chemical properties, especially when the concentration of $\mathrm{Ca}^{2+}$ is much higher than that of $\mathrm{Mg}^{2+}$. Hence, it is vital to design highly selective, sensitive, and simple sensors that can recognize $\mathrm{Mg}^{2+}$ without the interference of $\mathrm{Ca}^{2+}{ }^{23,44}$

Among the reported fluorescence sensors, ${ }^{45-54}$ diarylethene derivatives are the most promising candidates owing to their excellent thermal stability, remarkable fatigue resistance, and rapid response time. ${ }^{55-57}$ Furthermore, the recognized ions could induce a stable transformation between diarylethene molecule and complex, and these properties make it possible for the application in logic gates. ${ }^{58}$ Although much work in diarylethenes based on ion recognition has been finished, ${ }^{59-65}$ the sensors for the selective detection of $\mathrm{Mg}^{2+}$ based on diarylethenes are rarely reported..$^{66}$

Herein, a new diarylethene-based fluorescent sensor (10) for $\mathrm{Mg}^{2+}$ was developed. By investigating the fluorescent spectrum and color changes of this sensor under the stimulation of chemical substance and lights in acetonitrile solution, it could be found that the fluorescence of 10 could be effectively regulated by $\mathrm{Mg}^{2+}$ and lights. Moreover, a systematic discussion of its photochromic and fluorescent properties was also recorded in the full text in detail.

\section{Experimental}

\section{General methods}

All the reagents used in the synthesis process were from a variety of commercial sources without further purification. All 
cations were added in the form of their corresponding metal nitrates except for $\mathrm{Sn}^{2+}$ and $\mathrm{Hg}^{2+}$ (their counter anion ions were chloride ions). Metal ion solutions $\left(0.1 \mathrm{~mol} \mathrm{~L}^{-1}\right)$ were prepared by dissolving their respective metal salts in deionized water while performing the necessary dilutions according to each experimental device. Nuclear magnetic resonance hydrogen and carbon spectra were obtained with a Bruker AV400 spectrometer by using acetonitrile- $d_{3}$ as the solvents and tetramethylsilane (TMS) as an internal standard. High resolution mass spectrometry was collected on a Bruker Amazon SL ion trap mass spectrometer (ESI). The melting point was determined by a WRS-1B melting point instrument. UVvis absorption spectra were recorded with an Agilent $8453 \mathrm{UV} / \mathrm{vis}$ spectrometer. Fluorescence spectra were measured by using a Hitachi F-4600 fluorescence spectrophotometer with the slit width of $5.0 \mathrm{~nm}$ for both excitation and emission. Photoirradiation experiments were performed with an SHG-200 UV lamp and BMH250 visible lamp. Absolute fluorescence quantum yields were measured using an Absolute PL Quantum Yield Spectrometer QYC11347-11. Infrared spectra were collected on a Bruker Vertex70 spectrometer. The $\mathrm{pH}$ was measured with Ferromagnetic PHS3C $\mathrm{pH}$ meter. All of experiments were conducted at room temperature without special instructions.

\section{Synthesis of compound 10}

Compound 2 was synthesized according to the method reported in the previous work. ${ }^{67}$ Then compound 2 (0.094 g, $\left.0.2 \mathrm{mmol}\right)$ was dissolved in $5.0 \mathrm{~mL}$ absolute methanol, followed by the addition of 2-amino-4-methylphenol ( $0.025 \mathrm{~g}, 0.2 \mathrm{mmol})$. After the mixture was stirred at room temperature for 6.0 hours, the reaction system was placed in a freezer for overnight freezing (Scheme 1). It can be seen that a yellow solid precipitated and was washed three times with anhydrous methanol $(5.0 \mathrm{~mL} \times 3)$ and dried to get the target compound 10 (0.096 g, yield: 83\%). Mp: $435-437$ K. ${ }^{1} \mathrm{H}$ NMR (400 MHz, acetonitrile- $d_{3}$, TMS), $\delta(\mathrm{ppm}): 2.02(\mathrm{~s}, 3 \mathrm{H}), 2.12(\mathrm{~s}, 3 \mathrm{H}), 2.24(\mathrm{~s}, 3 \mathrm{H}), 2.29(\mathrm{~s}, 3 \mathrm{H}), 6.84$ $(\mathrm{d}, J=8.4 \mathrm{~Hz}, 1 \mathrm{H}), 7.04(\mathrm{~d}, J=8.6 \mathrm{~Hz}, 1 \mathrm{H}), 7.32(\mathrm{~s}, 2 \mathrm{H}), 7.58(\mathrm{~s}$, $1 \mathrm{H}), 8.08(\mathrm{~d}, J=8.6 \mathrm{~Hz}, 1 \mathrm{H}), 8.40(\mathrm{~d}, J=8.4 \mathrm{~Hz}, 1 \mathrm{H}), 8.79(\mathrm{~s}, 1 \mathrm{H})$, 8.94 (s, $1 \mathrm{H})$ (Fig. S1 $\dagger$ ). ${ }^{13} \mathrm{C}$ NMR (100 MHz, acetonitrile- $d_{3}$, TMS), $\delta$ (ppm): 10.7, 12.2, 14.6, 20.3, 105.0, 115.2, 115.9, 122.4, 125.5, $125.8,130.2$, 130.9, 133.9, 135.6, 139.3, 144.6, 147.1, 147.6, 151.2, 154.6, 157.9, 159.1, 171.1 (Fig. S2†). HRMS: $m / z=$ $578.1313\left[\mathrm{M}+\mathrm{H}^{+}\right]^{+}$. Calcd 578.1337 (Fig. S3†).

\section{Results and discussion}

\section{Photochromism of 10}

Fig. 1 shows the photochromic properties of 10 by UV/vis light studied in acetonitrile $\left(2.0 \times 10^{-5} \mathrm{~mol} \mathrm{~L}^{-1}\right)$ at room

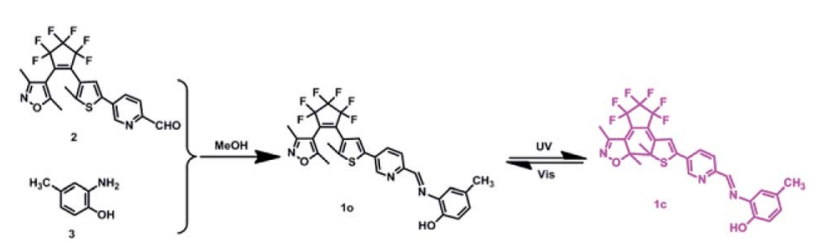

Scheme 1 The synthetic route and photochromism of 10. temperature. Two absorption bands of compound 10 at $338 \mathrm{~nm}(\varepsilon$ $\left.=2.94 \times 10^{4} \mathrm{~mol}^{-1} \mathrm{~L} \mathrm{~cm}^{-1}\right)$ and $381 \mathrm{~nm}\left(\varepsilon=2.67 \times 10^{4} \mathrm{~mol}^{-1}\right.$ $\mathrm{L} \mathrm{cm}^{-1}$ ) were observed, respectively. When irradiated with $297 \mathrm{~nm}$ light, the ring-closed isomer 1c was regenerated and a new absorption band centered at $536 \mathrm{~nm}\left(\varepsilon=1.93 \times 10^{3} \mathrm{~mol}^{-1}\right.$ $\mathrm{L} \mathrm{cm}^{-1}$ ) appeared, owing to a larger $\pi$-electron delocalization formed in the molecule. ${ }^{68}$ When the photostationary state (PSS) was reached, an isosbestic point was observed at $407 \mathrm{~nm}$, indicating a reversible two-component photochromic reaction. ${ }^{69}$ At the same time, there was a visible change of the color from colorless to pink. On the contrary, when irradiated with visible light $(\lambda>500 \mathrm{~nm})$, the absorption spectrum and the color of the solution could be quickly recovered to that of $\mathbf{1 0}$. The cyclization and cycloreversion quantum yields of 10 were determined to be 0.023 and 0.004 , respectively, with 1,2-bis(2-methyl-5-phenyl-3thienyl)perfluorocyclopentene as a reference ${ }^{70}$ On the other hand, the fatigue resistance of 10 was measured in acetonitrile by alternative irradiation of UV/vis lights at room temperature. The results showed that 10 times coloration-decoloration cycles between 10 and $1 \mathrm{c}$ could cause $20 \%$ degradation (Fig. S4†).

\section{Selectivity of 10 to metal ions}

The experiments of fluorescence selectivity of 10 toward various metal ions (5.0 equiv. of 1o) such as $\mathrm{Al}^{3+}, \mathrm{Cu}^{2+}, \mathrm{Sn}^{2+}, \mathrm{Ca}^{2+}, \mathrm{K}^{+}$, $\mathrm{Ag}^{+}, \mathrm{Ni}^{2+}, \mathrm{Ba}^{2+}, \mathrm{Zn}^{2+}, \mathrm{Mn}^{2+}, \mathrm{Cd}^{2+}, \mathrm{Sr}^{2+}, \mathrm{Hg}^{2+}, \mathrm{Co}^{2+}, \mathrm{Cr}^{3+}, \mathrm{Fe}^{3+}$, $\mathrm{Pb}^{2+}$, and $\mathrm{Mg}^{2+}$ in acetonitrile were performed. As shown in Fig. 2, upon excitation at $350 \mathrm{~nm}$, the fluorescence of 10 was notably changed only when $\mathrm{Mg}^{2+}$ was added. The addition of other metal ions resulted in no obvious effects on the fluorescence emission of 1o, except for the addition of $\mathrm{Cd}^{2+}$. These results showed the ability of $\mathbf{1 0}$ for distinguishing $\mathrm{Mg}^{2+}$ from other metals ions. Therefore, the diarylethene 10 could be used as a selective fluorescent sensor for $\mathrm{Mg}^{2+}$ in acetonitrile. In addition, the experiments of fluorescence response of 10 to $\mathrm{Mg}^{2+}$ in aqueous solution were also performed. As shown in Fig. $55, \uparrow$ there are no obvious changes in fluorescence with the addition of $\mathrm{Mg}^{2+}$, due to the poor water solubility of $\mathbf{1 0}$.

\section{Fluorescence studies of 10 toward $\mathbf{M g}^{2+}$}

The fluorescence titration experiment of 10 toward $\mathrm{Mg}^{2+}$ in acetonitrile was also investigated. As shown in Fig. 3A, 10

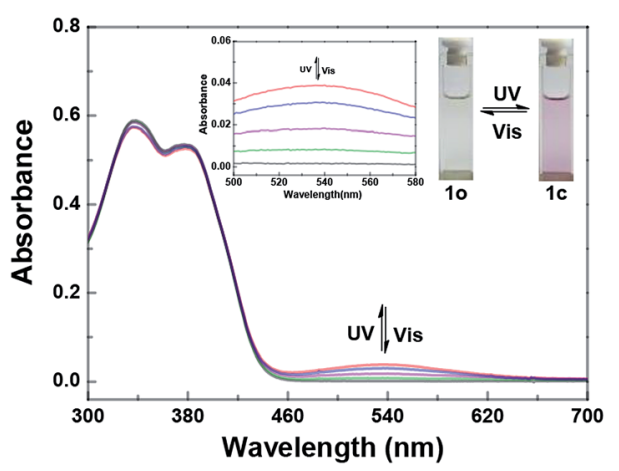

Fig. 1 Changes in the absorption spectra of 10 upon irradiation with $\mathrm{UV} / \mathrm{vis}$ lights in acetonitrile $\left(2.0 \times 10^{-5} \mathrm{~mol} \mathrm{~L}^{-1}\right)$. 

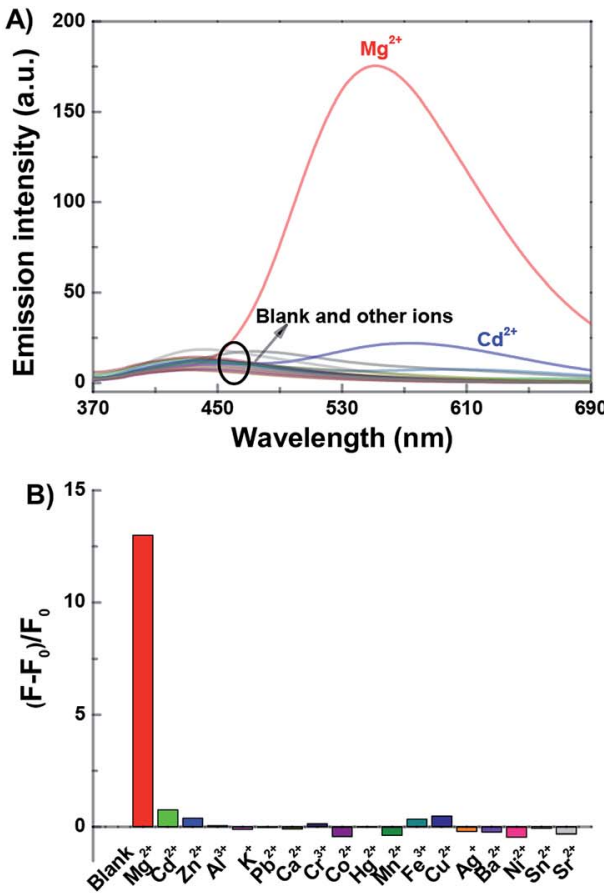

C)

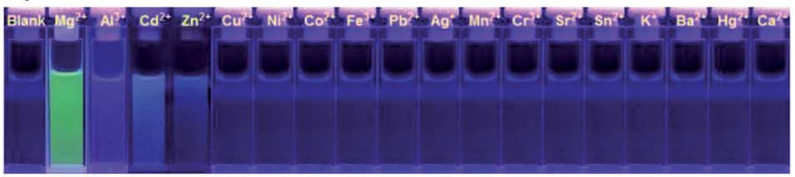

Fig. 2 Upon addition various metal ions to $10\left(2.0 \times 10^{-5} \mathrm{~mol} \mathrm{~L}^{-1}\right.$ in acetonitrile): (A) fluorescence emission spectral changes; (B) emission intensity changes; (C) fluorescent photos $\left(\lambda_{\mathrm{ex}}=350 \mathrm{~nm}\right.$ ).

exhibited a very weak emission at $442 \mathrm{~nm}$ with $350 \mathrm{~nm}$ excitation. With the gradual addition of $\mathrm{Mg}^{2+}$, the emission increased inch by inch, accompanied by a clear red shift from $442 \mathrm{~nm}$ to $552 \mathrm{~nm}$. When the amount of $\mathrm{Mg}^{2+}$ reached to 3.0 equivalents of 1o, the fluorescence intensity achieved its maximum (Fig. S6 $\dagger$ ), and the absolute quantum yield of fluorescence was determined to be 0.013 . At the same time, the fluorescent color changed from dark purple to green, which was coincident with the changes in the fluorescence spectra. Reversely, with the addition of EDTA (10.0 equivalents of 1o), the fluorescence spectrum recovered gradually to that of $\mathbf{1 0}$, indicating that the complexation reaction between 10 and $\mathrm{Mg}^{2+}$ was reversible. The weak fluorescence of the original 10 was attributed to the $\mathrm{C}=\mathrm{N}$ bond isomerization, which has long been known as the dominant decay process. ${ }^{71,72}$ However, a stable chelate $10-\mathbf{M g}^{2+}\left(\mathbf{1 0}^{\prime}\right)$ was formed in the presence of $\mathrm{Mg}^{2+}$. The isomerization of $\mathrm{C}=\mathrm{N}$ bond was inhibited, which increased the rigidity of the molecule, resulting in the chelation enhanced fluorescence (CHEF) effect. $^{73}$

The fluorescence switching property of $\mathbf{1 0}^{\prime}$ was also investigated. As shown in Fig. 3B, the emission intensity of $\mathbf{1 0}^{\prime}$ gradually decreased with the irradiation of $297 \mathrm{~nm}$ light, due to the formation of closed-ring isomer $1 \mathbf{c}-\mathbf{M g}^{2+}\left(\mathbf{1} \mathbf{c}^{\prime}\right) \cdot{ }^{74}$ When the PSS was reached, the fluorescence of $\mathbf{1 0}^{\prime}$ was quenched by $37 \%$,
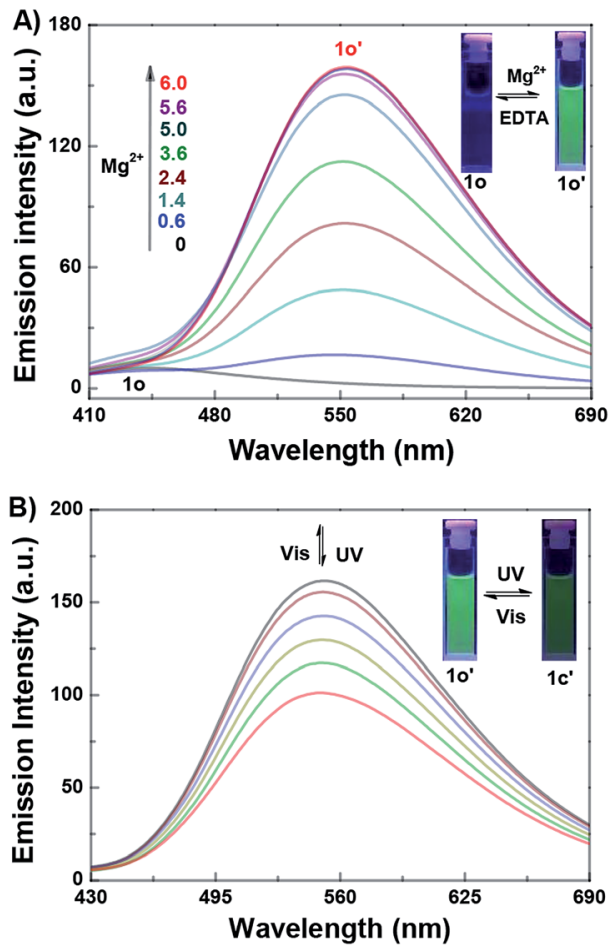

Fig. 3 (A) Fluorescence spectral changes of $10\left(2.0 \times 10^{-5} \mathrm{~mol} \mathrm{~L}^{-1}\right.$ in acetonitrile) induced by $\mathrm{Mg}^{2+}\left(0-6.0 \times 10^{-5} \mathrm{~mol} \mathrm{~L}^{-1}\right)$; (B) fluorescence spectral changes of $10^{\prime}\left(2.0 \times 10^{-5} \mathrm{~mol} \mathrm{~L}^{-1}\right.$ in acetonitrile), upon irradiation with UV/vis lights $\left(\lambda_{\mathrm{ex}}=350 \mathrm{~nm}\right)$.

accompanied by the fluorescent color changed from green to dark green. Reversely, the fluorescence spectrum of $1 \mathbf{1 o}^{\prime}$ could be recovered upon irradiation with visible light $(\lambda>500 \mathrm{~nm})$. In another way, the fluorescence spectral responses of the closedring isomer 1c to $\mathrm{Mg}^{2+}$ were also studied (Fig. S7†). With the addition of $\mathrm{Mg}^{2+}$, the emission intensity of 1c was obviously enhanced, and the emission peak shifted from $442 \mathrm{~nm}$ to $552 \mathrm{~nm}$. When the amount of $\mathrm{Mg}^{2+}$ reached 3.0 equivalents, the fluorescence spectrum was consistent with that from 1o' with $297 \mathrm{~nm}$ light. Meanwhile, the fluorescent color changed from dark to dark green. Reversely, upon the addition of EDTA (10.0 equivalents of 10), the fluorescence spectrum of $1 \mathbf{c}^{\prime}$ recovered immediately to that of 1c, showing that the complexationdecomplexation reaction between $1 \mathrm{c}$ and $\mathrm{Mg}^{2+}$ was also reversible.

Additionally, to evaluate the effects of $\mathrm{pH}$ on the sensor, the fluorescence spectral changes of $10-\mathrm{Mg}^{2+}$ over different $\mathrm{pH}$ values were also studied (Fig. $\mathrm{S} 8 \dagger$ ), the $\mathrm{pH}$ was adjusted by dropping an appropriate amount of the aqueous solution of $\mathrm{HCl}$ and $\mathrm{NaOH}$ into acetonitrile, and was measured with Ferromagnetic PHS-3C pH meter. The results showed the optimal pH range for the fluorescence emission of $10-\mathrm{Mg}^{2+}$ is $7-9$. At the same time, the experiments of fluorescence response of 10 to $\mathrm{Mg}\left(\mathrm{NO}_{3}\right)_{2}, \mathrm{MgCl}_{2}$, and $\mathrm{Mg}\left(\mathrm{ClO}_{4}\right)_{2}$ were also performed. As shown in Fig. S9, $\uparrow$ the emission intensity of $\mathbf{1 0}+\mathrm{Mg}\left(\mathrm{NO}_{3}\right)_{2}$ was much higher than that of $\mathbf{1 0}+\mathrm{MgCl}_{2}$ and $\mathbf{1 0}+\mathrm{Mg}\left(\mathrm{ClO}_{4}\right)_{2}$. The results indicated the counter anions have certain influence on the sensing of $\mathrm{Mg}^{2+}$. 


\section{Complexation mechanism of 10 with $\mathrm{Mg}^{2+}$}

Job's plot analysis was performed to prove the complexation of $10-\mathrm{Mg}^{2+}$ according to the previous report. ${ }^{75}$ The result showed that the emission intensity approached the maximum when the molar fraction of $\left[\mathrm{Mg}^{2+}\right] /\left([\mathbf{1 0}]+\left[\mathrm{Mg}^{2+}\right]\right)$ was about 0.5 , suggesting a $1: 1$ binding stoichiometry between 10 and $\mathrm{Mg}^{2+}$ in acetonitrile (Fig. 4). Meanwhile, the binding constant $\left(K_{\mathrm{a}}\right)$ of $1 \mathrm{o}$ and $\mathrm{Mg}^{2+}$ was determined to be $1.14 \times 10^{2} \mathrm{~L} \mathrm{~mol}^{-1}$ with the slope and intercept of the linearity $(R=0.998)$ (Fig. S10†). According to the reported method, ${ }^{76}$ the limit of detection of 10 toward $\mathrm{Mg}^{2+}$ was calculated to be $3.58 \times$ $10^{-7} \mathrm{~mol} \mathrm{~L}^{-1}$ (Fig. S11 $\dagger$ ). Therefore, 10 could serve as a highly sensitive fluorescent sensor for the detection of $\mathrm{Mg}^{2+}$ in acetonitrile.

Furthermore, ${ }^{1} \mathrm{H}$ NMR titration experiments were carried out in acetonitrile- $d_{3}$ to further prove the coordination of $\mathbf{1 0}$ and $\mathrm{Mg}^{2+}$. As shown in Fig. 5, with the addition of $\mathrm{Mg}^{2+}$, the $\mathrm{Hb}$ signal displayed a downfield shift of $0.01 \mathrm{ppm}$ from $6.84 \mathrm{ppm}$ to $6.85 \mathrm{ppm}$, and the Ha resonance signal at $7.32 \mathrm{ppm}$ disappeared completely, indicating the coordinated bond of $\mathrm{O}-\mathrm{Mg}^{2+}$ was formed. At the same time, the Hc on the pyrimidine displayed a shift of $0.02 \mathrm{ppm}$ from $8.40 \mathrm{ppm}$ to $8.38 \mathrm{ppm}$, showing the formation of the coordinate bond of $\mathrm{N}-\mathrm{Mg}^{2+}$. These results indicated that the $\mathrm{O}$ of the hydroxyl group, the $\mathrm{N}$ of pyrimidine are the most likely binding sites. Moreover, the HRMS analysis was also carried out to confirm the interaction between 10 and $\mathrm{Mg}^{2+}$. The testing sample was prepared by adding $\mathrm{Mg}^{2+}$ to 10 in acetonitrile, and the result indicated that a signal located at $\mathrm{m} / \mathrm{z}$ $=663.0922$ was consistent well with the ensemble $\left[10+\mathrm{Mg}^{2+}+\right.$ $\left.\mathrm{NO}_{3}{ }^{-}\right]^{+}$( $\mathrm{m} / \mathrm{z}$ calcd: 663.0987$)$ (Fig. S12 $\dagger$ ). In addition, the IR spectral experiments of 10 and $10-\mathrm{Mg}^{2+}$ have been also performed at room temperature. As shown in Fig. S13, $\uparrow$ the peak at $1608 \mathrm{~cm}^{-1}$ corresponds to $\mathrm{C}=\mathrm{N}$ stretching. Upon the complexation of 10 and $\mathrm{Mg}^{2+}$, the peak at $1608 \mathrm{~cm}^{-1}$ shifted to $1635 \mathrm{~cm}^{-1}$ due to the rigidification of the imine bond. Besides, the peak at $3440 \mathrm{~cm}^{-1}$ assigned to the stretching vibration of $-\mathrm{OH}$ shifted to $3408 \mathrm{~cm}^{-1}$. The strong absorption peak at $1383 \mathrm{~cm}^{-1}$ was attributed to the added $\mathrm{NO}_{3}{ }^{-}$. These results further proved that 10 and $\mathrm{Mg}^{2+}$ formed the $1: 1$ complex.

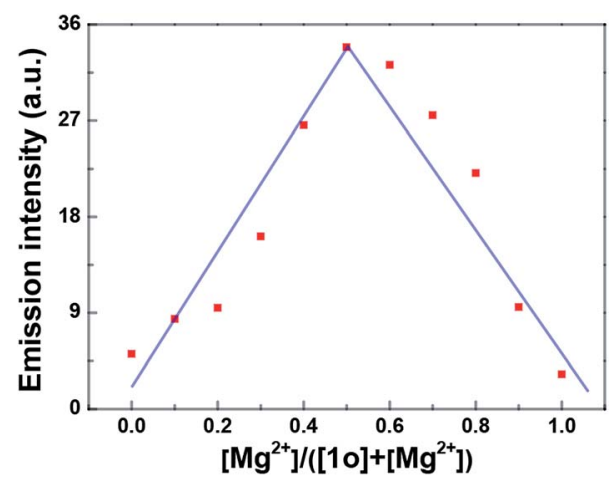

Fig. 4 Job's plot showing the $1: 1$ complex of 10 and $\mathrm{Mg}^{2+}$ in acetonitrile $\left(2.0 \times 10^{-5} \mathrm{~mol} \mathrm{~L}^{-1}\right)$.

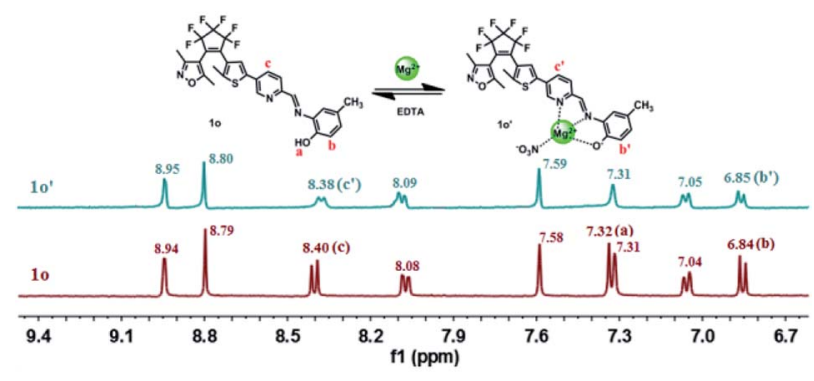

Fig. 5 Changes in ${ }^{1} \mathrm{H}$ NMR of 10 and $10^{\prime}$ in acetonitrile- $d_{3}$ (Inset shows the proposed binding mode of $10^{\prime}$ complex).

Based on these results, the proposed binding mode was shown in Scheme 2.

\section{Application in practical sample and logic circuit}

To study the practical application ability of $\mathbf{1 0}$ in $\mathbf{M g}^{2+}$ detection, the competitive experiments for the fluorescence response of 10 in the presence of $\mathrm{Mg}^{2+}$ and other metal ions were carried out in acetonitrile. As shown in Fig. S14, $\dagger$ the fluorescence response of 10 to $\mathrm{Mg}^{2+}$ was not affected by other competing metal ions, expect for $\mathrm{Cu}^{2+}, \mathrm{Co}^{2+}, \mathrm{Ni}^{2+}$. The results indicated that 10 has reasonable anti-interference ability on sensing $\mathrm{Mg}^{2+}$ in acetonitrile. Meantime, the application of 10 to real samples was also researched. The $\mathrm{Mg}^{2+}$ content in actual water samples from the Gan-Jiang River in Nanchang, Jiangxi province was measured. Table 1 showed the results determined with 10 after the addition of a moderate amount of $\mathrm{Mg}^{2+}$. The recoveries ranged from $94.3 \%$ to $103 \%$. The results indicated that 10 could be used to detect $\mathrm{Mg}^{2+}$ in real samples with high accuracy. Furthermore, on the basis of the photoswitching characteristics of 10 modulated by either UV/vis lights or chemical reagents stimuli in acetonitrile, a logic circuit was constructed with four input signals including In1: $297 \mathrm{~nm}$ light, In2: >500 nm light, In3: $\mathrm{Mg}^{2+}$, In4: EDTA and one output signal (Opt: emission intensity at $552 \mathrm{~nm}$ ) (Fig. S15, Table S1†). ${ }^{77,78}$ These results show that sensor 10 has certain practical value in real sample detection and logic circuit.

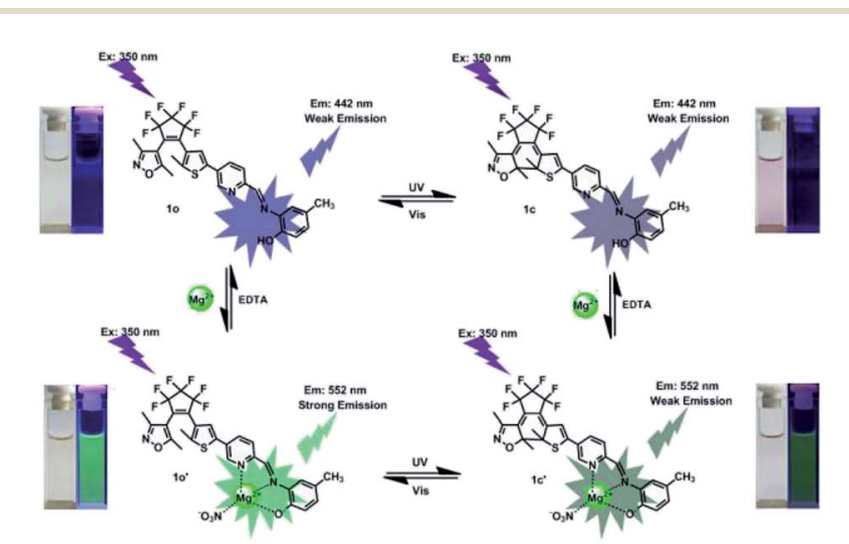

Scheme 2 Dual-controlled fluorescent-switching behavior of 10 induced by $\mathrm{Mg}^{2+} /$ EDTA and UV/vis light. 
Table 1 Application in actual water sample detection for $\mathrm{Mg}^{2+}$

\begin{tabular}{lllc}
\hline Sample no. & $\begin{array}{l}\mathrm{Mg}^{2+} \text { added } \\
(\mu \mathrm{M})\end{array}$ & $\begin{array}{l}\mathrm{Mg}^{2+} \text { determined } \\
(\mu \mathrm{M})\end{array}$ & $\begin{array}{l}\text { Recovery } \\
(\%)\end{array}$ \\
\hline 1 & 4 & 4.11 & 103 \\
2 & 8 & 7.63 & 95.4 \\
3 & 12 & 11.32 & 94.3 \\
4 & 16 & 16.39 & 102 \\
\hline
\end{tabular}

\section{Conclusions}

In summary, a highly selective fluorescent sensor toward $\mathrm{Mg}^{2+}$ based on diarylethene and 4-methylphenol unit was successfully developed. This sensor exhibited outstanding photochromic and fluorescent switching properties in acetonitrile solution. The application results indicated that the sensor could be used to detect $\mathrm{Mg}^{2+}$ in real samples. Furthermore, a logic circuit was designed with the fluorescence intensity at $552 \mathrm{~nm}$ as output signal, the UV/vis lights and $\mathrm{Mg}^{2+}$ /EDTA as input signals. All of the results will be helpful for the design and synthesis of new sensors for the recognition of $\mathrm{Mg}^{2+}$ with high selectivity in the future.

\section{Conflicts of interest}

There are no conflicts of interest to declare.

\section{Acknowledgements}

The authors are grateful for the financial support from the National Natural Science Foundation of China (41867053), the "5511" science and technology innovation talent project of Jiangxi (2016BCB18015), the key project of Natural Science Foundation of Jiangxi Province (20171ACB20025), the Project of the Science Funds of the Education Office of Jiangxi (GJJ160773), the Young Talents Project of Jiangxi Science and Technology Normal University (2015QNBJRC004), the Project of Jiangxi Science and Technology Normal University Advantage Sci-Tech Innovative Team (2015CXTD002).

\section{Notes and references}

1 M. J. Cromie, Y. Shi and T. Latifi, Cell, 2006, 125, 71-84.

2 G. Farruggia, S. Iotti and L. Prodi, J. Am. Chem. Soc., 2006, 128, 344-350.

3 L. Jin, Z. Guo and Z. Sun, Sens. Actuators, B, 2012, 161, 714720.

4 D. Ray, A. Nag and A. Jana, Inorg. Chim. Acta, 2010, 363, 28242832.

5 B. O'Rourke, P. H. Backx and E. Marban, Science, 1992, 257, 245-248.

6 C. Schmitz, A. L. Perraud and C. O. Johnson, Cell, 2003, 114, 191-200.

7 Y. Zhao, A. M. Ren and L. Y. Zou, Theor. Chem. Acc., 2011, 130, 61.
8 S. Ishijima, A. Uchibori and H. Takagi, Arch. Biochem. Biophys., 2003, 412, 126-132.

9 H. C. Politi and R. R. Preston, NeuroReport, 2003, 14, 659668.

10 H. Rubin, Arch. Biochem. Biophys., 2007, 458, 16-23.

11 F. I. Wolf, A. Torsello and S. Fasanella, Mol. Aspects Med., 2003, 24, 11-26.

12 K. Seki, K. Aizawa and T. Sugaoi, Chem. Lett., 2008, 37, 872873.

13 B. O'Rourke, P. H. Backx and E. Marban, Science, 1992, 257, 245-248.

14 R. Bogoroch and L. F. Belanger, Anat. Rec., 1975, 183, 437447.

15 H. O. Trowbridge and J. L. Seltzer, J. Periodontal Res., 1967, 2, 147-153.

16 L. Wang, W. Qin and X. Tang, J. Phys. Chem. A, 2011, 115, 1609-1616.

17 N. E. L. Saris, E. Mervaala and H. Karppanen, Clin. Chim. Acta, 2000, 294, 1-26.

18 J. A. M. Maier, Mol. Aspects Med., 2003, 24, 137-146.

19 M. Barbagallo and L. J. Dominguez, Arch. Biochem. Biophys., 2007, 458, 40-47.

20 T. Hashimoto, K. Nishi and J. Nagasao, Brain Res., 2008, 1197, 143-151.

21 R. Swaminathan, Clin. Biochem. Rev., 2003, 24, 47.

22 W. Jahnen-Dechent and M. Ketteler, Clin. Kidney J., 2012, 5, 3-14.

23 R. M. Touyz, Front. Biosci., 2004, 9, 1278-1293.

24 Y. Rayssiguier, E. Gueux and W. Nowacki, Magnesium Res., 2006, 19, 237-243.

25 M. Barbagallo, L. J. Dominguez and A. Galioto, Mol. Aspects Med., 2003, 24, 39-52.

26 J. Zhu, Y. Qin and Y. Zhang, Anal. Chem., 2009, 82, 436-440.

27 H. Hifumi, A. Tanimoto and D. Citterio, Analyst, 2007, 132, 1153-1160.

28 M. Ishida, Y. Naruta and F. Tani, Angew. Chem., Int. Ed., 2010, 49, 91-94.

29 S. Patra and P. Paul, Dalton Trans., 2009, 40, 8683-8695.

30 K. B. Kim, H. Kim and E. J. Song, Dalton Trans., 2013, 42, 16569-16577.

31 S. Goswami, A. Manna and S. Paul, Dalton Trans., 2013, 42, 8078-8085.

32 V. K. Gupta, N. Mergu and L. K. Kumawat, Sens. Actuators, B, 2015, 207, 216-223.

33 G. Farruggia, S. Iotti and L. Prodi, J. Am. Chem. Soc., 2007, 129, 1470.

34 H. Hama, T. Morozumi and H. Nakamura, Tetrahedron Lett., 2007, 48, 1859-1861.

35 K. C. Song, M. G. Choi and D. H. Ryu, Tetrahedron Lett., 2007, 48, 5397-5400.

36 H. M. Kim, P. R. Yang and M. S. Seo, J. Org. Chem., 2007, 72, 2088-2096.

37 Y. Liu, Z. Y. Duan and H. Y. Zhang, J. Org. Chem., 2005, 70, 1450-1455.

38 B. J. Sanghavi, W. Varhue and J. L. Chávez, Anal. Chem., 2014, 86, 4120-4125. 
39 B. J. Sanghavi, S. Sitaula and M. H. Griep, Anal. Chem., 2013, 85, 8158-8165.

40 B. J. Sanghavi, S. M. Mobin and P. Mathur, Biosens. Bioelectron., 2013, 39, 124-132.

41 B. J. Sanghavi and A. K. Srivastava, Electrochim. Acta, 2010, 55, 8638-8648.

42 B. J. Sanghavi and A. K. Srivastava, Electrochim. Acta, 2011, 56, 4188-4196.

43 P. S. Hariharan and S. P. Anthony, RSC Adv., 2014, 4, 4156541571.

44 H. Sharma, N. Kaur and A. Singh, J. Mater. Chem. C, 2016, 4, 5154-5194.

45 V. K. Gupta, N. Mergu and L. K. Kumawat, Sens. Actuators, B, 2016, 223, 101-113.

46 M. Liu, X. Yu and M. Li, RSC Adv., 2018, 8, 12573-12587.

47 G. T. Selvan, V. Chitra and V. M. V. Enoch Israel, New J. Chem., 2018, 42, 902-909.

48 J. H. Hu, J. B. Li and Y. Sun, RSC Adv., 2017, 7, 29697-29701. 49 Y. Ma, H. Liu and S. Liu, Analyst, 2012, 137, 2313-2317.

50 G. Men, C. Chen and S. Zhang, Dalton Trans., 2015, 44, 27552762.

51 Q. Lin, J. J. Gruskos and D. Buccella, Org. Biomol. Chem., 2016, 14, 11381-11388.

52 X. Zhu, C. He and D. Dong, Dalton Trans., 2010, 39, 1005110055.

53 G. Zhang, J. J. Gruskos and M. S. Afzal, Chem. Sci., 2015, 6, 6841-6846.

54 G. Wang, J. Qin and L. Fan, J. Photochem. Photobiol., A, 2016, 314, 29-34.

55 M. Irie, T. Fukaminato, T. Sasaki, N. Tamai and T. Kawai, Nature, 2002, 420, 759.

56 H. Tian and S. Yang, Chem. Soc. Rev., 2004, 33, 85-97.

57 K. Matsuda and M. Irie, J. Photochem. Photobiol., C, 2004, 5, 169-182.

58 S. Z. Pu, H. Ding and G. Liu, J. Phys. Chem. C, 2014, 118, 7010-7017.
59 Q. Zou, X. Li and J. Zhang, Chem. Commun., 2012, 48, 20952097.

60 H. Liu and Y. Chen, Eur. J. Org. Chem., 2009, 30, 5261-5265. 61 Q. Zou, J. Jin and B. Xu, Tetrahedron, 2011, 67, 915-921.

62 Z. Zhou, H. Yang and M. Shi, ChemPhysChem, 2007, 8, 12891292.

63 Z. Zhou, S. Xiao and J. Xu, Org. Lett., 2006, 8, 3911-3914.

64 Z. Li, C. Zhang and Y. Ren, Org. Lett., 2011, 13, $6022-6025$.

65 S. Z. Pu, D. Jiang and W. Liu, J. Mater. Chem., 2012, 22, 35173526.

66 S. Q. Cui, Z. Tian and S. Z. Pu, RSC Adv., 2016, 6, 1995719963.

67 S. Z. Pu, Z. P. Tong, G. Liu and R. J. Wang, J. Mater. Chem. C, 2013, 1, 4726-4739.

68 M. Irie, Chem. Rev., 2000, 100, 1685-1716.

69 Z. X. Li, L. Y. Liao and W. Sun, J. Phys. Chem. C, 2008, 112, 5190-5196.

70 S. Z. Pu, J. Xu and L. Shen, Tetrahedron Lett., 2005, 46, 871875.

71 Z. Wang, S. Q. Cui, S. Y. Qiu and S. Z. Pu, Spectrochim. Acta, Part A, 2018, 205, 21-28.

72 W. K. Dong, X. L. Li, L. Wang, Y. Zhang and Y. J. Ding, Sens. Actuators, B, 2016, 229, 370-378.

73 E. T. Feng, Y. Y. Tu, C. B. Fan, G. Liu and S. Z. Pu, RSC Adv., 2017, 7, 50188-50194.

74 Z. Wang, S. Q. Cui, S. Y. Qiu and S. Z. Pu, RSC Adv., 2018, 8, 29295-29300.

75 J. S. Wu, W. M. Liu and X. Q. Zhuang, Org. Lett., 2007, 9, 3336.

76 H. Wang, B. Wang and Z. Shi, Biosens. Bioelectron., 2015, 65, 91-96.

77 Z. Wang, S. Q. Cui, S. Y. Qiu and S. Z. Pu, J. Photochem. Photobiol., A, 2018, 367, 212-218.

78 Z. Wang, S. Q. Cui, S. Y. Qiu and S. Z. Pu, Tetrahedron, 2018, 74, 7431-7437. 